Заболотна А. В., Заболотний О. І., кандидати сільськогосподарських наук Уманський національний університет садівництва

\title{
ФОРМУВАННЯ ДЕЯКИХ ПОКАЗНИКІВ СТРУКТУРИ ВРОЖАЮ ПШЕНИЦІ ЯРОӤ ЗА ЗАСТОСУВАННЯ ГЕРБЦЦИДУ «ЛІНТУР 70 WG, в.Г.» І РЕГУЛЯТОРА РОСТУ РОСЛИН «ЕМІСТИМ С»
}

\section{Рецензент - доктор сільськогосподарських наук Г. М. Господаренко}

Досліджено формування таких показників структури врожаю пшениці ярої як кількість продуктивних стебел, продуктивна кушистість, кількість $i$ маса зерен із колоса за внесення гербійду «Лінтур 70 $W G$, в.г.» у нормах 120, 150 i 180 г/га як окремо, так $i$ y бакових сумішах із регулятором росту рослин «Емістим С». Встановлено, щуо застосування оптимальних норм гербіцииду сприяє покращчанню циих показників, а найвищі їх значення спостерігаються у разі сумісного внесення 120 г/га «Лінтуру 70 WG, в.г.» у баковій суміші з «Емістимом С». Внесення максимальної норми гербіииду (180 г/га) як окремо, так $i$ y суміші з "Емістимом С» має інгібуючу дію на рослини пшениці ярої, щзо проявляється у зниженні досліджуваних показників структури врожаю посівів культури.

Ключові слова: пшениия яра, гербіџид «Лінтур $70 \mathrm{WG}$, в.г.», регулятор росту «Емістим $C$ », стеблостій, продуктивна кущистість, кількість і маса зерен, колос.

Постановка проблеми. Провідну роль у харчовому забезпеченні людства відіграють зернові злаки, три з яких - пшениця, кукурудза і рис - посідають чільне місце [1]. Вчені схиляються до думки, що значення пшениці в майбутньому ще більше зростатиме, й саме вона стане найважливішою у світі. Висока врожайність пшениці ярої може сформуватися лише в такому агроценозі, який за своїми параметрами, і передусім за густотою рослин, кущистістю, розміром колоса, кількістю та масою зерен у колосі буде найближчим до оптимального $[3,5,6]$. Поряд із тим, як доведено багаторічними науковими дослідженнями та практикою на виробництві, наявність бур'янів істотно знижує продуктивність посівів сільськогосподарських культур, адже бур'яни можуть виносити 3 грунту в $1,2-1,5$ рази більше елементів живлення, ніж потребують рослини пшениці. Тому боротьба з бур'янами, переважно за допомогою хімічного методу, займає чільне місце у сучасних технологіях вирощування польових культур. Використання гербіцидів у посівах сільськогосподарських культур знижує винос бур'янами елементів живлення в $1,7-4,5$ рази [10].
Аналіз основних досліджень і публікацій, у яких започатковано розв'язання проблеми. Літературні дані свідчать, що за внесення гербіцидів в оптимальних нормах рослини краще розвиваються, кущаться, порівняно $з$ контролем без гербіцидів, де значна забур'яненість пригнічує ріст і розвиток культурних рослин. Використання хімічних засобів захисту посівів в оптимальних нормах має також позитивний вплив на продуктивність колоса та масу 1000 зерен. Так, за даними В. В. Сахненка [8], активний ріст і розвиток рослин пшениці на ділянках, звільнених від бур'янів за допомогою гербіцидів, сприяє збільшенню розміру колосків, зерна в них та підвищенню маси зерен порівняно з контролем без гербіцидів.

Окрім того суттєва роль у підвищенні продуктивності сільськогосподарських культур належить сучасним регуляторам росту рослин. Так, за даними С. П. Пономаренка та Б. М. Черемхи [7], внесення «Емістиму С» збільшує продуктивність кущіння ячменю ярого на 25-30 \%.

Мета і завдання досліджень. Метою наших досліджень було встановити, як впливає гербіцид «Лінтур $70 \mathrm{WG}$, в.г.» та регулятор росту «Емістим С» на показники структури врожаю пшениці ярої.

Завданням досліджень було дослідити формування кількості продуктивних стебел пшениці ярої, коефіцієнту продуктивного кущіння, кількості та маси зерен із колоса за різних норм гербіциду «Лінтур 70 WG, в.г.», внесених окремо і у бакових сумішах 3 «Емістимом С».

Матеріали і методи досліджень. Досліди виконували в польових і лабораторних умовах кафедри біології Уманського національного університету садівництва в посівах пшениці ярої сорту Колективна 3 впродовж 2010-2012 років. Вегетуючі рослини у фазі повного кущення обприскували гербіцидом «Лінтур 70 WG, в.г.» $(120,150$ і 180 г/га) та регулятором росту «Емістим С» (10 мл/га) як окремо, так і у бакових сумішах.

Повторність досліду - триразова. Грунт - 


\section{СІЛЬСЬКЕ ГОСПОДАРСТВО. РОСЛИННИЦТВО}

чорнозем опідзолений важкосуглинковий, вміст гумусу в орному шарі - 3,2-3,3\%. Ступінь насиченості профілю грунту основами - в межах 89,8-92,5\%, реакція грунтового розчину середньокисла (pHксl 5,5), гідролітична кислотність - 1,93-2,26 смоль/кг грунту, вміст рухомих сполук фосфору та калію (за методом Чирикова) - 120-132 мг/кг грунту, азоту лужногідролізованих сполук (за методом Корнфілда) - 103 мг/кг грунту [2].

Препарати вносили обприскувачем ОГН-600 iз витратою робочого розчину 300 л/га. Показники структури врожаю пшениці ярої визначали згідно із загальноприйнятими методиками [4].

Результати досліджень. За підрахунку кількості продуктивних стебел (що мають значний вплив на величину врожаю) нами було встановлено, що їх чисельність змінювалася залежно від норм і способів застосування препаратів. Так, за внесення «Емістиму С» без гербіциду кількість продуктивних стебел рослин пшениці ярої зросла у середньому за роки досліджень у порівнянні 3 контролем I на 7 \% (табл. 1).

За дії 120 г/га «Лінтуру 70 WG, в.г.» без «Емістиму С» кількість продуктивних стебел пере- вищувала контроль I на 6 \%, а в разі застосування 150 г/га гербіциду була найбільшою серед варіантів досліду, де вносили «Лінтур 70 WG, в.г.» без «Емістиму С» - на $16 \%$ більше за контроль I. Дія 180 г/га гербіциду збільшувала кількість продуктивних стебел у посівах пшениці ярої на 4 \%.

Найбільш активно 3-поміж варіантів досліду із внесенням «Лінтуру 70 WG, в.г.» і «Емістиму С» продуктивні стебла формувалися за сумісної дії препаратів.

Застосовуючи 120 г/га гербіциду в суміші 3 регулятором росту кількість продуктивних стебел зросла порівняно з контролем I на 19 \%, тоді як за внесення 150 г/га - на $17 \%$.

Менш активно впливало на формування продуктивних стебел внесення 180 г/га «Лінтуру 70 WG, в.г.» у суміші 3 «Емістимом С»- тут їх кількість перевищувала контроль I на 6 \%.

У процесі визначення коефіцієнту продуктивного кущіння нами встановлено, що він також залежав від норм і способів застосування препаратів.

Зокрема, за внесення «Емістиму С» коефіцієнт продуктивного кущіння зріс проти контролю I на $7 \%$.

1. Кількість продуктивних стебел і продуктивна кущистість рослин пшениці ярої за внесення гербіциду «Лінтур 70 WG, в.2.» $\mathrm{i}$ «Емістиму С»

\begin{tabular}{|l|c|c|c|c|c|}
\hline Варіант досліду & 2010 p. & 2011 p. & 2012 p. & $\begin{array}{c}\text { Середне } \\
\text { за три роки }\end{array}$ & $\begin{array}{c}\text { До конт- } \\
\text { ролю, \% }\end{array}$ \\
\hline Без препаратів і ручних прополю- & 445 & 450 & 432 & 442 & 100 \\
вань (контроль I) & 0,99 & 1,00 & 0,96 & 0,98 & 100 \\
\hline Без препаратів + ручні прополю- & 513 & 535 & 522 & 523 & 118 \\
вання (контроль II) & 1,15 & 1,21 & 1,17 & 1,16 & 119 \\
\hline «Емістим С» & 468 & 472 & 486 & 475 & 107 \\
& 1,04 & 1,05 & 1,08 & 1,06 & 107 \\
\hline «Лінтур 70 WG, в.г.»120 г/га & 463 & 477 & 472 & 471 & 106 \\
& 1,03 & 1,06 & 1,05 & 1,05 & 107 \\
\hline «Лінтур 70 WG, в.г.»150 г/га & 508 & 517 & 508 & 511 & 116 \\
& 1,13 & 1,15 & 1,13 & 1,14 & 116 \\
\hline «Лінтур 70 WG, в.г.»180 г/га & 454 & 459 & 463 & 459 & 104 \\
& 1,01 & 1,02 & 1,03 & 1,02 & 104 \\
\hline «Лінтур 70 WG, в.г.»120 г/га + & 517 & 540 & 526 & 528 & 119 \\
«Емістим С» & 1,15 & 1,20 & 1,17 & 1,17 & 120 \\
\hline «Лінтур 70 WG, в.г.»150 г/га + & 508 & 526 & 517 & 517 & 117 \\
«Емістим С» & 1,13 & 1,17 & 1,15 & 1,15 & 117 \\
\hline «Лінтур 70 WG, в.г.»180 г/га + & 463 & 477 & 472 & 471 & 106 \\
«Емістим C» & 1,03 & 1,06 & 1,05 & 1,05 & 107 \\
\hline НІР 05 & 8 & 15 & 9 & & \\
\hline
\end{tabular}

Примітка. Над рискою - кількість продуктивних стебел, шт./м², під рискою - продуктивна кущистість 


\section{СІЛЬСЬКЕ ГОСПОДАРСТВО. РОСЛИННИЦТВО}

За застосування 120 г/га «Лінтуру 70 WG, в.г.» без «Емістиму С» коефіцієнт продуктивного кущіння перевищував контроль I також на 7 \%, а за дії 150 г/га - на $16 \%$. Найменшим цей показник серед варіантів досліду із застосуванням гербіциду без регулятора росту був за застосування 180 г/га препарату, однак на $4 \%$ перевищував контроль I (табл. 1).

Внесення «Лінтуру 70 WG, в.г.» у суміші 3 «Емістимом С» більш активно вплинуло на величину коефіцієнта продуктивного кущіння пшениці ярої порівняно із застосуванням препаратів окремо. Так, найвищий показник продуктивної кущистості серед усіх варіантів досліду був за дії 120 г/га «Лінтуру 70 WG, в.г.» у суміші 3 регулятором росту, де він зростав у порівнянні 3 контролем I на $20 \%$. Внесення 150 г/га гербіциду в суміші з регулятором росту сприяло збільшенню коефіцієнта на $17 \%$ у порівнянні 3 контролем I. За дії 180 г/га «Лінтуру 70 WG, в.г.» продуктивна кущистість перевищувала контроль I на 7 \%.

У ході дослідження кількості та маси зерен у колосі пшениці ярої нами встановлено, що за застосування «Емістиму С» кількість зерен із колоса в середньому за роки досліджень була на рівні контролю I (табл. 2). За внесення 120 г/га гербіциду «Лінтур 70 WG, в.г.» кількість зерен 3 одного колоса збільшилася у порівнянні 3 контролем I на $2 \%$, тоді як за дії 150 г/га - на $5 \%$. Застосування 180 г/га гербіциду істотно не впливало на зміну кількості зерен із колоса.

За сумісного внесення «Лінтуру $70 \mathrm{WG}$, в.г.» 3 «Емістимом С» кількість зерен із колоса була більшою проти варіантів досліду, де гербіцид вносили без регулятора росту. Так, за дії 120 г/га «Лінтуру 70 WG, в.г.» в суміші 3 «Емістимом С» кількість зерен із колоса зросла у порівнянні 3 контролем I на $9 \%$, а за внесення 150 г/га - на $6 \%$. Застосування максимальної норми гербіциду в суміші 3 «Емістимом С» мало впливало на цей показник. У ході дослідження маси зерна 3 колоса нами встановлено, що вона також змінювалася залежно від норм і способів застосування препаратів. Так, за внесення «Емістиму С» маса зерен у колосі збільшилася порівняно 3 контролем I у середньому за роки досліджень на $2 \%$. За застосування 120 і 150 г/га «Лінтуру 70 WG, в.г.» без «Емістиму С» маса зерен у колосі перевищувала контроль I відповідно до норм препарату на 4 та 9 \% (табл. 2). За сумісної дії препаратів формування маси зерна з колоса відбувалося більш активно у порівнянні з внесенням гербіциду і регулятора росту окремо.

2. Кількість і маса зерен у колосі пшениці ярої за дії гербіциду «Лінтур 70 WG, в.2.» $i$ «Емістиму C»

\begin{tabular}{|l|c|c|c|c|c|}
\hline Варіант досліду & 2010 p. & 2011 p. & 2012 p. & $\begin{array}{c}\text { Середнє } \\
\text { за три роки }\end{array}$ & $\begin{array}{c}\text { До конт- } \\
\text { ролю, \% }\end{array}$ \\
\hline Без препаратів і ручних & 23,2 & 23,8 & 21,0 & 22,7 & 100 \\
прополювань (контроль I) & 0,82 & 0,85 & 0,74 & 0,80 & 100 \\
\hline Без препаратів + ручні пропо- & 24,9 & 26,0 & 22,9 & 24,6 & 108 \\
лювання (контроль II) & 0,92 & 1,00 & 0,85 & 0,92 & 115 \\
\hline \multirow{2}{*}{ «Емістим С» } & 23,3 & 23,8 & 21,0 & 22,8 & 100 \\
& 0,84 & 0,87 & 0,75 & 0,82 & 102 \\
\hline \multirow{2}{*}{ «Лінтур 70 WG, в.г.»120 г/га } & 23,7 & 24,5 & 21,0 & 23,1 & 102 \\
& 0,85 & 0,90 & 0,75 & 0,83 & 104 \\
\hline \multirow{2}{*}{ «Лінтур 70 WG, в.г.»150 г/га } & 24,2 & 25,5 & 21,7 & 23,8 & 105 \\
& 0,89 & 0,94 & 0,79 & 0,87 & 109 \\
\hline \multirow{2}{*}{ «Лінтур 70 WG, в.г.»180 г/га } & 23,6 & 24,2 & 21,0 & 22,9 & 101 \\
& 0,83 & 0,87 & 0,74 & 0,81 & 102 \\
\hline «Лінтур 70 WG, в.г.» 120 г/га + & 25,0 & 26,2 & 23,0 & 24,7 & 109 \\
«Емістим С» & 0,93 & 1,01 & 0,86 & 0,94 & 117 \\
\hline «Лінтур 70 WG, в.г.»150 г/га + & 24,5 & 25,8 & 22,0 & 24,1 & 106 \\
«Емістим С» & 0,91 & 0,97 & 0,81 & 0,90 & 112 \\
\hline «Лінтур 70 WG, в.г.» 180 г/га + & 23,8 & 24,5 & 21,7 & 23,3 & 103 \\
«Емістим С» & 0,87 & 0,91 & 0,78 & 0,86 & 107 \\
\hline \multirow{2}{*}{ НІР 05} & 0,5 & 0,3 & 0,6 & & \\
\hline
\end{tabular}

Примітка. Над рискою - кількість зерен із колоса, шт.; під рискою - маса зерен із колоса, г 
За внесення 120 г/га «Лінтуру 70 WG, в.г.» у суміші 3 «Емістимом С» маса зерна у колосі перевищувала контроль I на $17 \%$. У разі дії 150 г/га гербіциду з регулятором росту цей показник знижувався, однак був більшим за контроль I на $12 \%$. Застосування 180 г/га «Лінтуру 70 WG, в.г.» у суміші з «Емістимом С» сприяло збільшенню маси зерен у колосі на 6,9 \% більше за

\section{БІБЛІОГРАФІЯ}

1. Андрющенко A. 4-5 млн насінин на гектар - це оптимально / А. Андрющенко // Пропозиція. - 2002. - №1. - С. 40-41.

2. Господаренко Г. М. Особливості удобрення ярого ячменю 3 підсівом конюшини / Г. М. Господаренко // Ефективність хімічних засобів у підвищенні продуктивності сільськогосподарських культур / Зб. наук. праць Уманського ДАУ, 2001. - С. 47-56.

3. Дмитриев В. Е. Динамика формирования продуктивного стеблестоя и зерна яровой пшеницы / В. Е. Дмитриев // Зерновое хозяйство. -2006 . - №7. - С. 20-21.

4. Єщуенко В. О. Основи наукових досліджень в агрономії / [В. О. Єщенко, П. Г. Копитко, В. П. Опришко, П. В. Костогриз]; під ред. В. О. Сщенка. - К. : Дія. $-2005 .-288$ с.

5. Жайльбай $K$. Н. Влияние минеральных удобрений на урожайность и качество зерна яровой пшеницы в Казахстанском Приаралье / К. Н. Жайлыбай, А. М. Токтамысов, А. С. Сагиндыкова, Н.К. Нурмаш // Агрохимия. - 2005. - №11. - C. 43-48.

6. Карпова Л. В. Продуктивность озимой контроль I.

Висновок. Аналіз отриманих даних свідчить, що кращі показники досліджуваних елементів структури врожаю пшениці ярої (кількість продуктивних стебел, коефіцієнт продуктивного кущіння, кількість та маса зерна 3 колоса) формуються за застосування 120 г/га «Лінтуру 70 WG, в.г.» у суміші 3 «Емістимом С».

пшеницы при разных сроках сева / Л. В. Карпова // Зерновое хозяйство. - 2005. - №4. C. $26-29$.

7. Пономаренко С. П. Біостимулятори росту рослин у науковому забезпеченні АПК / С. П. Пономаренко, Б. М. Черемха // Пропозиція. - 1997. - №2. - С. 22-24.

8. Сахненко В. В. Застосування нових пестицидів в інтегрованій системі захисту озимої пшениці від найбільш поширених збудників хвороб в умовах Правобережного Лісостепу України: автореф. дис. ... канд. с.-г. наук: спец. 06.01.11 «Захист рослин» / В.В.Сахненко. - К., 1999. - $18 \mathrm{c}$.

9. Сорокин A. E. Структура повевов и фитометрические показатели яровой пшеницы Лада при разных уровнях применения средств химизации / А. Е. Сорокин, С. А. Бельченко // Зерновое хозяйство. - 2006. - №4. - С. 20-21.

10. Юла В. М. Особливості технології вирощування ярої твердої і м'якої пшениці в умовах Лісостепу України: автореф. дис. ...канд. с.-г. наук: спец. 06.01.09 «Рослинництво» / В. М. Юла. - К., 1998. 